criminal proceedings are offered. Priority directions of investigation of situational conditionality of proving in criminal proceedings are determined.

The use of a situational approach is justified in using all the basic means of proving in criminal proceedings. Since the algorithms of actions of authorized persons in the process of obtaining evidentiary information are determined by the specific situation in the proceedings, the use of technical and tactical-criminalistic methods and means of gathering and examining of evidence, as well as the use of already existing evidence in criminal proceedings, is situationally conditioned. On this basis, the situational conditionality and patterns of evidence in criminal proceedings are of particular scientific interest, and consideration of such regularities will optimize the recommendations of technical, tactical and methodological character developed by the forensic scientists.

Key words: forensic situation, situation, investigative situation, evidence, forensic recommendations.

DOI: 10.33766/2524-0323.88. 250-257

УДК 336.025:347.73

В. Г. Першин,

кандидат юридичних наук,

начальник відділу міжнародних зв' язків

Національної академії прокуратури України

(м. Київ, Україна)

e-mail: pershinv@gmail.com

iDhttps://orcid.org/0000-0002-7562-4964

\title{
РОЛЬ ФІНАНСОВОГО МОНІТОРИНГУ В МЕЖАХ ПРОТИДІЇ ЛЕГАЛІЗАЦІЇ ДОХОДІВ, ОДЕРЖАНИХ ЗЛОЧИННИМ ШЛЯХОМ
}

У статті розглядається проблематика ролі фінансового моніторингу в межах протидії легалізації доходів, одержаних злочинним шляхом. Зазначається про значне поширення цього негативного явища. Акцентується увага на транснаціональному характері «відмивання» брудних коштів. Пропонуються шляхи удосконалення діяльності системи фінансового моніторингу.

Ключові слова: фінансовий моніторинг, протидія легалізації доходів, «відмивання» грошей, функції публічного управління, злочинність.

Постановка проблеми. Станом на сьогодні Україна потребує суттєвого удосконалення діяльності в царині фінансового моніторингу. Причин такого стану справ достатньо багато. Одна із них полягає в необхідності протидії (легалізації) доходів, одержаних злочинним шляхом. Рівень злочинності, у тому числі й економічної, на жаль, має в Україні тенденцію до зростання. Такі ж невтішні показники й стосовно легалізації (відмивання) доходів, одержаних злочинним шляхом. Значною мірою вказане обумовлене загальним погіршенням криміногенної ситуації в державі та становленням системи фінансового моніторингу в Україні, наявністю низки нерозв'язаних у цьому аспекті проблем. Наразі ми є свідками активного розвитку фінансового законодавства та намагання з боку держави здійснювати реальне запобігання та 
протидію легалізації (відмивання) доходів, одержаних злочинним шляхом, фінансуванню тероризму та розповсюдженню зброї масового знищення.

Аналіз останніх досліджень і публікацій. Певні питання системи фінансового моніторингу досліджували такі фахівці, як: О. Ф. Андрійко, В. Т. Білоус, О. М. Бандурка, С. А. Буткевич, С. В. Васильчак, Л. К. Воронова, В. А. Журавель, А. Т. Ковальчук, Н. Р. Нижник, В. А. Некрасов, О. П. Орлюк, Л. А. Савченко, С. В. Сімов'ян, С. Г. Стеценко, О. С. Користін, Н. Я. Якимчук та інші. Водночас у юридичній науці наразі недостатньо системно розглядається роль фінансового моніторингу в межах протидії (легалізації) доходів, одержаних злочинним шляхом, що й обумовлює важливість дослідження вказаного питання.

Формування цілей. Метою цієї статті є розкриття загальних рис та особливостей, котрі характеризують роль фінансового моніторингу в межах протидії легалізації доходів, одержаних злочинним шляхом, що й обумовлюе важливість дослідження ролі фінансового моніторингу в межах протидії (легалізації) доходів, одержаних злочинним шляхом.

Виклад основного матеріалу. Практично кожна цивілізована держава намагається запровадити дієву систему фінансового моніторингу. Залежно від країни, указана система має певні особливості, проте є і спільні риси. Вони, серед іншого, виявляються у функціях і принципах. 3 позицій системного дослідження фінансового моніторингу як об'єкту адміністративно-правового наукового дослідження, ми пропонуємо такі функції фінансового моніторингу: запобіжну; координаційну; детінізації економіки; міжнародного співробітництва.

Утім, говорячи про принципи фінансового моніторингу, варто вказати на необхідність врахування існуючих підходів щодо принципів публічно-правової діяльності. Скажімо, С. Г. Стеценко в рамках адміністративно-правової парадигми, справедливо стверджує, що важливим фактором розуміння суті публічного управління є усвідомлення його принципів, під якими розуміються основні засади, закономірності, на яких базується публічне управління. Значення принципів адміністративного права полягає в тому, що вони, завдяки здійснюваному свідомо узагальненню, у стислому виді відбивають найсуттевіші характеристики вказаної галузі права. Оскільки формулювання принципів - це свідома творча діяльність науковців, практиків, фахівців у сфері адміністративного права та державного управління, доцільно виокремити такі вимоги до принципів публічного управління: відповідність нормам чинного законодавства; відбиття найсуттевіших, ключових закономірностей державного управління; відповідність меті публічного управління [1, с. 52-53].

Погоджуючись із такого роду постановкою питання, вважаємо, необхідно враховувати також і принципи інших, дотичних до фінансового моніторингу явищ, які нерідко виступають у якості об'єкту фінансового моніторингу. Так, приміром, основними принципами т. зв. «відмивання» грошей є таке: приховування дійсного власника і джерела надходження т. зв. «брудних» грошей (якщо після «відмивання» ім'я власника буде залишатися відомим, процес втрачає будь-який сенс); зміна номіналу купюр, призначених для «відмивання»; максимальне заплутування процесу; перебування грошей під постійним контролем їхнього власника [2, с. 68]. Не можна також не згадати про 
важливість здійснення фінансового моніторингу за формуванням виборчих фондів кандидатів та політичних партій під час виборів [3].

Чинне законодавство на рівні підзаконного нормативно-правового акту наказу Міністерства фінансів України, який присвячено принципам опрацювання одержаної від суб'єктів первинного фінансового моніторингу інформації про фінансові операції, що підлягають фінансовому моніторингу та критеріїв аналізу таких операцій, містить інформацію, відповідно до якої ці принципи та критерії призначені для використання Державною службою фінансового моніторингу України під час проведення аналізу повідомлень, отриманих від суб'єктів первинного фінансового моніторингу (далі - СПФМ), про фінансові операції, що можуть бути пов'язані з легалізацією (відмиванням) доходів, одержаних злочинним шляхом, або фінансуванням тероризму чи фінансуванням розповсюдження зброї масового знищення, й описує принципи опрацювання одержаної від СПФМ інформації про фінансові операції, котрі підлягають фінансовому моніторингу, та критерії аналізу фінансових операцій, що підлягають фінансовому моніторингу.

Опрацювання одержаної від СПФМ інформації про фінансові операції, які підлягають фінансовому моніторингу, базується на таких основних принципах: 1) повноти опрацювання інформації; 2) послідовності опрацювання інформації; 3) збереження та захисту інформації; 4) контролю за опрацюванням інформації; 5) своєчасності та об'єктивності опрацювання інформації; 6) незалежності та невтручання в діяльність СПФМ працівників Держфінмоніторингу при опрацюванні ними інформації; 7) категорійності обробки повідомлень про фінансові операції з урахуванням ризик-орієнтовного підходу; 8) усебічного використання інформації з інших передбачених законодавством джерел під час опрацювання інформації [4].

М. В. Борець у рамках своєї дисертаційної роботи зазначає про розуміння системи фінансового моніторингу у сфері запобігання та протидії легалізації (відмиванню) доходів, одержаних злочинним шляхом, як: 1) системи адміністративно-правових, фінансово-правових, кримінальноправових, міжнародно-правових, оперативно-розшукових та інших заходів, що здійснюються уповноваженими суб'єктами, - системи державного регулювання (у широкому розумінні); 2) системи постійного контролю щодо відстеження фінансових операцій уповноважених суб'єктів (первинного) фінансового моніторингу відповідно до встановлених критеріїв, одним із методів якого є фінансовий моніторинг (у вузькому розумінні) [5, с. 10]. Нам видається, що такого роду бачення в цілому є недостатньо повним, оскільки акцентує увагу лише на контролі та фактичній протидії цьому явищу. Варто все ж таки говорити про більш комплексний підхід, який містить запобігання, протидію, притягнення винних до відповідальності, підтримку ініціатив щодо інформування про виявлені факти легалізації злочинних коштів, міжнародну взаємодію в цій сфері.

Поняття «відмивання» (англ. топеy laundering) історично пов' язане з одним із перших та найбільш відомих способів легалізації злочинних доходів (коштів), які в 20-30-х роках минулого століття кримінальні групи Сполучених Штатів Америки, що отримували надприбутки від незаконної торгівлі горілчаними 
виробами під час дії т. зв. «сухого закону», «показували» (легалізували) їх, як здобуті внаслідок прання білизни, тобто «відмиті» через мережу пралень, що належала їм, хоча такого доходу від прання білизни неможливо було отримати [6, с. 27]. Подібна діяльність у подальшому набула нових горизонтів, суттево розширилась та вийшла за межі горілчаних виробів. На жаль, за роки незалежності Україна стикнулась із масовими спробами різних підприємців, високопосадовців, криміналитету тощо легалізувати кошти, отримані в протиправний спосіб. I держава повинна цьому запобігати. Одним із такого роду заходів, як свідчить європейський досвід, є підвищення фінансового контролю за особами, які мають можливість впливати на формування чинного законодавства, створюючи сприятливе законодавче підгрунтя для різного роду фінансових махінацій [7].

3 70-х роках двадцятого століття, у зв'язку зі стрімким розвитком, у першу чергу, інформаційних і фінансових технологій, світ став глобальним. Головні ролі у світовій економіці почали грати транснаціональні корпорації, які за своєю економічною потужністю й політичним впливом перебувають на рівні з деякими національними економіками. Це сприяло виникненню небувалих умов i можливостей для процвітання тіньової економіки, також прийняло глобальні масштаби у своїй діяльності. Сконцентрувавши у своїх руках колосальні активи, злочинний світ перейнявся наданням їм легального вигляду для можливості їх безперешкодного використання. У зв'язку з цим стали вкрай затребувані різні способи легалізації доходів, отриманих злочинним шляхом [8, с. 1].

Відмивання доходів, придбаних незаконно, сприяе криміналізації практично всієї системи суспільних відносин. Це соціально-негативне явище набуває міжнародного характеру й тому створює фінансову базу для існування злочинності, у тому числі організованої і транснаціональної. Накопичення капіталу злочинними формуваннями, впровадження його в цивільний обіг, а також використання за межами країни дозволяють отримувати значні переваги в конкурентній боротьбі, створюють несприятливий інвестиційний клімат і негативно впливають на розвиток національної економіки. Залучення коштів із злочинних джерел викликає в той же час дестабілізацію фінансових відносин, загрожує стабільності банківської системи в цілому [9]. Тут, на жаль, ми вимушені констатувати, що Україна за багатьма світовими рейтингами, котрі характеризують ступінь протидії злочинності, в основі якої лежить легалізація незаконно отриманих коштів, знаходиться далеко від чільних позицій.

Сьогодні в Україні питання, пов'язані з фінансовим моніторингом доходів, отриманих злочинних шляхом, набули великої ваги й перебувають у центрі уваги нашого суспільства. Актуальність даної проблеми полягає в тому, що припинення отримання доходів у тіньовому секторі економіки дозволить значно збільшити податкові надходження до державного бюджету, що особливо необхідно в умовах значного дефіциту бюджету України. Доходи, отримані злочинним шляхом, становлять серйозну небезпеку для законної економічної діяльності, дестабілізації існуючих фінансової та валютної систем, зниження добробуту населення, наповнення державного бюджету [10, с. 214].

Як видається, багато в чому належне наукове опрацювання та практична діяльність із протидії легалізації злочинних коштів гальмується через недостатню 
опрацьованість теоретико-методологічних питань, через нерозуміння фахівців, які займаються цими питаннями, базових засад фінансового моніторингу та його призначення. Дослідники вказують, що правовідносини у сфері фінансового моніторингу щодо протидії легалізації (відмиванню) доходів, одержаних злочинним шляхом носять системний характер і складаються не тільки із фінансово-правових відносин, а також із адміністративно-правових i кримінально-правових відносин, а також відносин у сфері міжнародного права й економічної теорії (тіньова економіка, детінізація економіки), організації оперативно-розшукової діяльності та ін. Фінансовий моніторинг є однією із складових системи протидії легалізації доходів, одержаних злочинним шляхом, або фінансуванню тероризму. Удосконалення і взаємодія елементів даної системи забезпечить ефективну протидію легалізації доходів, одержаних злочинним шляхом [11, с. 108]. Такого роду позиція засвідчує роль та значення взаємодії елементів комплексної системи протидії легалізації коштів, отриманих злочинним шляхом. Інакше досить непросто забезпечити боротьбу із цим негативним явищем та досягти позитивних результатів.

Однією з міжнародних тенденщій розвитку контрольної діяльності держави $є$ пошук нових інструментів, покликаних запобігти протиправним явищам у житті держави і суспільства 3 мінімальним втручанням у діяльність приватних осіб та організацій. Загострилися міжнародні та національні проблеми тероризму, наркоторгівлі, корупщї, що свідчить про те, що традищійні методи боротьби 3 ними є недостатньо ефективними [12]. Мусимо наголосити, що роль держави має бути схожою із діяльністю хірурга, який видаляє все непотрібне, натомість залишає в організмі людини всі життєздатні органи та тканини. Запобігаючи легалізації коштів, отриманих злочинним шляхом, держава через систему фінансового моніторингу та діяльність правоохоронних органів має видаляти всі злочинні прояви, натомість залишати ті підприємницькі структури, котрі не порушують закон чи діють у легальному правовому полі.

Висновки. Отже, на наше глибоке переконання, Україна здатна зробити суттєві кроки вперед у справі запобігання та протидії легалізації доходів, одержаних злочинним шляхом. Значною мірою це залежить від належної організації діяльності системи фінансового моніторингу, а також вдосконалення чинного законодавства в цьому напрямі.

\section{Використані джерела:}

1. Стеценко С. Г. Адміністративне право України: навч. посіб. Вид. 3-тє, перероб. та доп. К.: Атіка, 2011. 624 с.

2. Барановський О. І. «Відмивання» грошей: сутність та шляхи запобігання. Видво «Форт», 2003. 472 с.

3. Нестерович В. Ф. Конституційно-правові засади участі громадськості у фінансуванні федеральних виборчих кампаній у США. Вибори та демократія. 2011. № 2. C. $17-24$.

4. Про затвердження Принципів опрацювання одержаної від суб'єктів первинного фінансового моніторингу інформації про фінансові операції, що підлягають фінансовому моніторингу, та критеріїв аналізу таких операцій: Наказ Міністерства фінансів України від 10 березня 2015 р. № 306. 
5. Борець М. В. Адміністративно-правовий статус державних регуляторів у сфері запобігання та протидії легалізації (відмиванню) доходів, одержаних злочинним шляхом. Дис... канд. юрид. наук. 12.00.07. Київ, 2017. 234 с. $240 \mathrm{c}$.

6. Кернер Х.-Х., Дах Э. Отмывание денег. М.: Международные отношения, 1996.

7. Нестерович В. Ф. Зміни у конституційно-правовому регулюванні лобіювання у Німеччині та Франщії. Вісник Луганського державного університету внутрішніх справ імені Е. О. Дідоренка. 2015. № 2. С. 23-33.

8. Быченко Е. Г. Противодействие легализации (отмыванию) доходов, полученных преступным путём, и финансирования терроризма в условиях финансовой глобализации. Автореф. дис... канд. экон. наук. Москва, 2009. 22 с.

9. Николаев К. В. Организация системы финансового мониторинга в России: социологический анализ и перспективы развития: диссертация ... кандидата социологических наук: 22.00.08. Ростов-на-Дону, 2010. 164 с.

10. Борець М. В. Поняття і категорії у дослідженні питань з протидіїлегалізації доходів, одержаних злочинним шляхом. Вісник НТУУ «КПІ». Серія «Політологія. Соціологія. Право». 2013. Випуск 1 (17) . С. 105-109

11. Бормотова М. В., Мухіна К. О. Дослідження сутності поняття фінансовий моніторинг. Вісник економіки транспорту і промисловості. 2015. № 50. С. 214-217

12. Прошунин М. М. Финансовый мониторинг в системе противодействия легализации преступных доходов и финансированию терроризма: российский и зарубежный опыт. Дис. докт. юрид. наук. Москва, 2010. 404 с.

\section{References:}

1. Stetsenko, S. G. (2011) Administratyvne pravo Ukrainy: navch. posib. Vyd. 3-tie, pererob. ta dop. Kyiv: Atika. [in Ukrainian].

2. Baranovskyi, O. I. (2003) "Vidmyvannia" hroshei: sutnist ta shliakhy zapobihannia. Vyd-vo «Fort». [in Ukrainian].

3. Pro zatverdzhennia Pryntsypiv opratsiuvannia oderzhanoi vid sub'iektiv pervynnoho finansovoho monitorynhu informatsii pro finansovi operatsii, shcho pidliahaiut finansovomu monitorynhu, ta kryteriiv analizu takykh operatsii: Nakaz Ministerstva finansiv Ukrainy vid 10 bereznia 2015 r. № 306. [in Ukrainian].

4. Nesterovych, V. F. (2011) Konstytutsiyno-pravovi zasady uchasti hromads'kosti u finansuvanni federal'nykh vyborchykh kampaniy u SSHA. Vybory ta demokratiya - Elections and democracy, 2, 17-24. [in Ukrainian].

5. Borets, M. V. (2017) Administratyvno-pravovyi status derzhavnykh rehuliatoriv u sferi zapobihannia ta protydii lehalizatsii (vidmyvanniu) dokhodiv, oderzhanykh zlochynnym shliakhom. Doctor's thesis. Kyiv. [in Ukrainian].

6. Kerner, Kh.-Kh., Dakh, E. (1996) Otmyvanye deneh. Moskva: Mezhdunarodnyie otnoshenyia. [in Russian].

7. Nesterovych, V. F. (2015) Zminy u konstytutsiyno-pravovomu rehulyuvanni lobiyuvannya u Nimechchyni ta Frantsiyi. Visnyk Luhans'koho derzhavnoho universytetu vnutrishnikh sprav imeni E.O. Didorenka - Bulletin of the Luhansk State University of Internal Affairs Didorenko, 2, 23-33. [in Ukrainian].

8. Bychenko, E. H. (2009) Protyvodeistvye lehalyzatsyy (otmyvanyiu) dokhodov, poluchennykh prestupnym putiom, y fynansyrovanyia terroryzma $\mathrm{v}$ uslovyiakh fynansovoi hlobalyzatsyy. Extended abstract of candidate's thesis. Moskva. [in Ukrainian]. 
9. Nykolaev, K. V. (2010) Orhanyzatsyia systemy fynansovoho monytorynha v Rossyy: sotsyolohycheskyi analyz y perspektyvi razvytyia. Doctor's thesis. Rostov-na-Donu. [in Russian].

10. Borets, M. V. (2013) Poniattia i katehorii u doslidzhenni pytan z protydiilehalizatsii dokhodiv, oderzhanykh zlochynnym shliakhom. Visnyk NTUU «KPI». Seriia «Politolohiia. Sotsiolohiia. Pravo»-Bulletin of NTUU "KPI". Political Science Series. Sociology. Right", 1(17), 105109. [in Ukrainian].

11. Bormotova, M. V., Mukhina, K. O. (2015) Doslidzhennia sutnosti poniattia finansovyi monitorynh. Visnyk ekonomiky transportu i promyslovosti- Bulletin of Economics of Transport and Industry, 50, 214-217. [in Ukrainian].

12. Proshunyn, M. M. (2010) Fynansovyi monytorynh v systeme protyvodeistvyia lehalyzatsyy prestupnykh dokhodov y fynansyrovanyiu terroryzma: rossyiskyi i zarubezhnyi opyt. Doctor's thesis. Moskva. [in Russian].

Стаття надіӥшла до редколегії 18.11.2019

Першин В. Г., кандидат юридических наук, начальник отдела международных связей Национальной академии прокуратуры Украины (г. Киев, Украина)

\section{РОЛЬ ФИНАНСОВОГО МОНИТОРИНГА В РАМКАХ ПРОТИВОДЕЙСТВИЯ ЛЕГАЛИЗАЦИИ ДОХОДОВ, ПОЛУЧЕННЫХ ПРЕСТУПНЫМ ПУТЕМ}

В статье рассматривается проблематика роли финансового мониторинга в пределах противодействия легализации доходов, полученных преступным путем. Отмечается о широком распространении этого негативного явления. Акцентируется внимание на транснациональном характере т. наз. «отмывания» грязных денег. Предлагаются пути совершенствования деятельности системы финансового мониторинга.

Ключевые слова: финансовый мониторинг, противодействие легализации доходов, «отмывание» денег, функции публичного управления, преступность.

Pershin V.,

Candidate of Law, Head of International Relations National Academy of Public Prosecutor of Ukraine (Kyiv, Ukraine)

\section{THE ROLE OF FINANCIAL MONITORING IN THE LIMITS OF ANTI-LEGALIZATION OF INCOME PROVIDED BY A CRIMINAL WAY}

The article deals with the problem of the role of financial monitoring within the framework of counteracting the legalization of proceeds from crime.

As of today, Ukraine needs to significantly improve its financial monitoring activities. There are many reasons for this. One of them is the need to counteract (legalize) the proceeds of crime. The level of crime, including economic crime, unfortunately, tends to 
increase in Ukraine. The same disappointing figures are in place for the legalization (laundering) of proceeds of crime.

To a large extent, this is due to the general deterioration of the country's criminogenic situation and the establishment of a financial monitoring system in Ukraine, with the presence of a number of unresolved problems in this regard. We are currently witnessing the active development of financial legislation and the government's attempt to prevent and counteract the actual legalization (laundering) of proceeds of crime, terrorist financing and the proliferation of weapons of mass destruction.

It is noted that this negative phenomenon is widespread. Emphasis is placed on the transnational nature of "laundering" of dirty money. Virtually every civilized state tries to put in place an effective financial monitoring system. This system has its own characteristics depending on the country, but there are common features. They are, among other things, manifested in functions and principles. The ways of improving the activity of the financial monitoring system are proposed.

Key words: financial monitoring, counteraction to legalization of income, money laundering, public administration function.

DOI: $10.33766 / 2524-0323.88 .257-265$

УДК 343.98

В. М. Плетенець, кандидат юридичних наук, доцент, доцент кафедри криміналістики, судової медицини та психіатрії

Дніпропетровського державного університету внутрішніх справ

(м. Дніпро, Україна)

e-mail: viktor_plet@i.ua

iDhttps://orcid.org/0000-0002-3619-8624

\section{МОЖЛИВОСТІ ВИКОРИСТАННЯ СЛІДЧИМ КРИТИЧНОГО МИСЛЕННЯ В УМОВАХ ПРОТИДІЇ РОЗСЛІДУВАННЮ}

Стаття присвячена висвітленню можливостей використання слідчим критичного мислення в умовах протидії розслідуванню.

Наголошується, що процедури та стратегії критичного мислення мають використовуватися для вирішення неординарних практичних завдань, котрі неможливо вирішити машинально, із застосуванням наявних знань та умінь. Звертається увага на те, що набуття слідчими навичок оцінки кожного розслідуваного кримінального провадження сприятиме формуванню такого якісного рівня, що не дозволить припуститися помилок розслідування. Підкреслюється, що постійний тиск з боку зацікавлених осіб не повинен впливати на рішення слідчого, які мають бути самостійними та грунтуватися на критичному аналізі матеріалів провадження.

Ключові слова: протидія розслідуванню, критичне мислення, рішення слідчого, аналіз провадження.

Постановка проблеми. Діяльність слідчого має пізнавально-пошуковий характер пізнання події минулого, що здійснюється шляхом збору відомостей (с) Плетенець В. М., 2019 